\title{
Assessment of the water facilities in primary schools in the Niger Delta. WASH education series 1.
}

\author{
${ }^{1}$ Kotingo E. L. MBBS, DMAS, FMAS, ${ }^{2}$ Ayerite A. L. MBBS, \\ ${ }^{2}$ Chukwuma C. B., MBBS. \\ ${ }^{1}$ Department of Obstetrics and Gynaecology, Federal Medical Centre, Yenagoa, Bayelsa State, Nigeria. \\ ${ }^{2}$ Deparment of Community Medicine, University of Port Harcourt Teaching Hospital, Choba, Rivers State, \\ Nigeria.
}

\begin{abstract}
:
Background: A huge number of children in their millions get debilitated and pass on consistently from water borne diseases and absence of essential sanitation and hygiene. Objectives: To assess the source, functionality and availability of water in primary schools in Obio-Akpor Local Government area.Methodology: This was a descriptive cross sectional study that involved the use of an observational checklist to get information from 25 primary schools and the administration of 480 self-administered structured questionnaires to pupils in the primary schools. A multistage sampling was employed in choosing the pupils that were studied.Results: 22 (88.00\%) of the primary schools had borehole with electric pump and 2 (8.00\%) of the primary schools had no water supply, 1 (4\%) of the primary schools had piped water to the school premises and 2 (8.00\%) of the primary schools had no water supply. The study also revealed that; of the 23 primary schools that had a source of water, 18 (78.26\%) had constant water supply and 5 (21.74\%) occasionally had water supply, pupils in 20 $(86.96 \%)$ schools had to walk a distance of $<5$ minutes from the source to the common point of use, and pupils in $3(13.04 \%)$ schools had to walk $>5$ minutes. Conclusion: The water facilities as observed from this study, met with internationally acceptable standards. However, development of maintenance plan and strict compliance with admission proceedings such that the number of pupil admitted into both private and public primary schools do not exceed the capacity provided for by the existing water facilities is inimical to communicable disease prevention.
\end{abstract}

Keywords: Water Sanitation and Hygiene, Water access, Water supply, Water quality, Water source, Primary schools.

\section{Introduction}

A huge number of children in their millions get debilitated and pass on consistently from water borne diseases and absence of essential sanitation.The water facilities as observed from this study, met with internationally acceptable standards. However, development of maintenance plan and strict compliance with admission proceedings such that the number of pupil admitted into both private and public primary schools do not exceed the capacity provided for by the existing water facilities is inimical to communicable disease prevention.

UNICEF has assessed that more than $50 \%$ of the world's schools need clean toilets, drinking water and hygiene lessons for all school children. Around $40 \%$ of an expected 578 million school children are invaded with worms and 88 million children under 15 years old with schistosomiasis. ${ }^{1}$

WHO appraises that in 2008 diarrhoeal disease killed 2.5 million individuals. ${ }^{2}$ For kids under five, this load is more noteworthy than the joined together trouble of HIV/AIDS and malaria. ${ }^{3}$ An aggregate of 58 nations from all continents reported a combined aggregate of 589,854 cholera cases in 2011, speaking to an expand of $85 \%$ from 2010 . The best extent of cases was accounted for in the Island of Hispaniola and African landmass. ${ }^{4}$ Such malady trouble particularly between the age of 5 and 14, a time of extreme physical and learned improvement, have a negative impact on development, nutritional status, physical exercises, comprehension and school execution. ${ }^{1}$

\section{Water sources in primary Schools}

There are two sorts of wellsprings of drinking water for schools i.e. improved and unimproved. Improved are "piped water sources" and does not so much infer safety. The improved sources utilized as a part of the schools are funneled water frameworks, engine pumps/jackass pumps and hand pumps. Water pumps utilized as a part of the schools could be mechanized or hand pumps. Mechanized pumps incorporate; turbine pumps and radial pumps (regularly called borehole). These pumps are energized with power. The engineering utilized as a part of hand pumps is quick exhausting from schools where power is accessible, on the grounds that 
it's a shallow depth innovation (introduced at a depth of 20-40 feet) and accordingly the water is by and large contaminated and changes taste. Hand pumps are just introduced as the option wellspring of water. For schools with normal enrolment of 250 understudies hand pump is not a practical wellspring of water. ${ }^{5}$ The wellspring of water in elementary schools ought to ideally be an improved/secured source fitted with a mechanized pump and the separation from the source to the normal purpose of utilization ought to in a perfect world not be long. ${ }^{5}$

\section{Water availability in Primary schools}

The real amount of water needed will rely on upon various variables, for example, atmosphere, sort of water utilization offices and neighborhood water utilization drills. Drinking water ought to be accessible all through the school day and children urged to drink it, in light of the fact that even dehydration decreases youngsters' capacity to concentrate and may harm their wellbeing in long haul. In schools without a safe drinking source, children and staff may need to convey their drinking water with them to school. ${ }^{6}$ The essential amount of water that ought to be accessible for day schools ought to be 5 liters for every understudy for every day for all school children and staff. Extra amounts of water that ought to be accessible for day schools for flush toilets ought to be 10 to 20 liters for every individual for every day for flush toilets, while for poor flush can ought to be 1.5 to 3 liters for every individual for every day. ${ }^{6}$

\section{Functional status of school water facilities}

Accessibility of infrastructure does not intimate that it is appropriately working or utilized by the target beneficiaries, unless it is legitimately worked and kept up. The purposes behind non-working of water offices in schools may incorporate absence of an upkeep arrangement, incessant force blackout with no reinforcement power supply to electric pumps, an excess of clients for few taps, bolted taps etc. ${ }^{5}$

\section{Objectives:}

To assess the source and availability of water in primary schools in Obio-Akpor Local Government area.

\section{1: $\quad$ Study Design}

\section{Methodology}

This is a descriptive cross sectional study of pupils and teaching staff of primary schools in ObioAkpor local government area.

\section{2: $\quad$ Study Area}

The study was carried out in primary schools located in Obio-Akpor local government area of Rivers State. Obio-Akpor is a Local Government Area in the metropolis of Port Harcourt, one of the major centres of economic activities in Nigeria, and one of the major cities of the Niger Delta, located in Rivers State. The Local Government Area covers 260 sq.km and as at the 2006 Census, it held a population of 464,789. Obio-Akpor, with its headquarters at Rumuokoro, has 45 Public (State Government owned) and 71 Private schools. ${ }^{7}$

\section{3: Study Population}

This comprised of teaching staff and pupils in primary five and six in primary schools in Obio-Akpor local Government area.

\section{4: $\quad$ Eligibility Criteria}

- Teacher in a primary school

- Pupils of a primary school

\section{5: Inclusion Criteria}

- Pupil in primary five or six, attending a primary school in Obio-Akpor.

- Teacher in primary school in Obio-Akpor

\section{6: Exclusion Criteria}

- Non-teaching staff of a primary school in Obio-Akpor.

- Pupil not in primary five or six.

\section{7: Sample Size Determination}

A suitable sample size of teachers and pupils was selected within the target population. This sample size was derived as follows; 
A prevalence rate of $39.7 \%$ was used. Precision (i.e. margin of sampling error) tolerated was set at $5 \%$, at $95 \%$ confidence interval, using the formula

$$
\mathrm{n}=\mathrm{pq} /(\mathrm{e} / 1.96)^{2}
$$

Where $\mathrm{n}=$ sample size

$\mathrm{P}=$ prevalence rate $=39.7 \%$

$\mathrm{q}=100-\mathrm{p}=100-39.7=60.3 \%$

$\mathrm{e}=$ margin of sampling error tolerated at $95 \%$ confidence interval $=5 \%$

Hence, $\mathrm{n}=39.7 \times 60.3 /(5 / 1.96)^{2}$

$\mathrm{n}=368.00$

Adjusting for an attrition or non-compliance rate of $30 \%$

Hence, $30 \%$ attrition $=30 / 100 \times 368.00=110.40$

Thus, the adjusted sample size $=368.00+110.40=478.40$

Working sample size $\approx 480$ subjects

\section{8: $\quad$ Sampling Method}

This was a multistage random sampling in which a sample frame of all the primary schools in ObioAkpor LGA was acquired from the Obio-Akpor Primary School Education Board. There are 45 Public and 71 Private schools. Among these, 10 public and 15 private schools were selected by simple random sampling and the number of pupils to be sampled in each of these schools was predetermined. A stratified sampling by sex and class level was then done to select the number of males and females in each arm of the primary five and six class level to be studied, following which a simple random sampling was done to select an arm in each of the primary five and six class level to be studied. Finally, a simple random sampling was done to select the actual male and female subjects to be given questionnaire. Also, 25 observational checklists (one for each school) which were filled in conjunction with a school teacher/administrator were used for this study.

\section{9: $\quad$ Study Instrument}

A structured self-administered questionnaire was designed and used to collect information from pupils, as well as an observational check list. The information that was collected includes; water source and type of water facilities, water availability and accessibility, toilet facilities (type, location, number), sanitary condition of toilets, awareness of teachers on School Health policy, school curriculum on hygiene education, teacher training on hygiene education, hygiene education resources, provision for hand washing, hand washing facilities (location and access to water and soap), hand washing practice.

\subsection{0: Data Analysis}

The data was processed using windows excel 2007. Summary statistics, sample frequencies and crossed tabulations was then computed.

\subsection{1: Limitations of Study}

- Difficulty in gaining access to some schools, which was overcome by repeated appeals and repeated visitations

- Some pupils could not read, as such, the questionnaires had to be given to others that could understand them.

- Some pupils tried to copy from their peers, necessitating adequate separation of pupils from one another during the administration of questionnaires.

\subsection{2: Consent and Ethical Approval}

A permission to study was obtained from the Obio-Akpor local Government Primary School Board, following the presentation of a duly obtained letter of consent from the department of Preventive and Social Medicine of the University of Port Harcourt. At the beginning of the study, the administrators of the selected primary schools were duly informed. The reason for the study and procedure for data collection was explained to the teachers and pupils before collection of data from them. 


\section{1: Introduction}

\section{Results}

A total of 25 checklist and 480 self-administered structured questionnaires were used to collect information from teachers/school administrators and pupils in primaries 5 and 6 respectively. Out of this number, 14 questionnaires were excluded from the analysis because they were not properly filled or returned. Thus, the respondent rate of this study was $97.08 \%$.

\section{2: Demographic data}

\subsection{1: Sex distribution of pupils}

The sex distribution of the 466 respondents as seen in table 7.1 below, showed that $187(40.13 \%)$ of respondents were male and $279(59.87 \%)$ were female.

Table 7.1: Sex distribution of pupils in primaries 5 and 6

\begin{tabular}{|c|c|c|c|c|c|c|}
\hline \multirow[b]{3}{*}{$\begin{array}{l}\text { Type } \\
\text { school }\end{array}$} & \multicolumn{4}{|c|}{ Sex of pupils } & \multirow[b]{3}{*}{ Total No } & \multirow[b]{3}{*}{ Total \% } \\
\hline & \multicolumn{2}{|c|}{ Male } & \multicolumn{2}{|c|}{ Female } & & \\
\hline & $\begin{array}{l}\text { Absolute } \\
\text { Frequency }\end{array}$ & $\begin{array}{l}\text { Relative } \\
\text { Frequency } \\
(\%)\end{array}$ & $\begin{array}{l}\text { Absolute } \\
\text { Frequency }\end{array}$ & $\begin{array}{l}\text { Relative } \\
\text { Frequency (\%) }\end{array}$ & & \\
\hline Private & 102 & 36.69 & 176 & 63.31 & 278 & 59.66 \\
\hline Public & 85 & 45.21 & 103 & 54.79 & 188 & 40.34 \\
\hline Total & 187 & 40.13 & 279 & 59.87 & 466 & 100.00 \\
\hline
\end{tabular}

\subsection{2: Sex distribution of teachers}

The sex distribution of the 25 teachers as seen in table 7.2 below, showed that $7(28.00 \%)$ of respondents were male and $18(72.00 \%)$ were female.

Table 7.2: Sex distribution of teachers

\begin{tabular}{|c|c|c|c|c|c|c|}
\hline \multirow{3}{*}{ Type of school } & \multicolumn{4}{|c|}{ Sex of teachers } & \multirow{3}{*}{ Total No } & \multirow{3}{*}{ Total $\%$} \\
\hline & \multicolumn{2}{|c|}{ Male } & \multicolumn{2}{|c|}{ Female } & & \\
\hline & $\begin{array}{l}\text { Absolute } \\
\text { Frequency }\end{array}$ & $\begin{array}{l}\text { Relative } \\
\text { Frequency (\%) }\end{array}$ & $\begin{array}{l}\text { Absolute } \\
\text { Frequency }\end{array}$ & $\begin{array}{l}\text { Relative } \\
\text { Frequency }(\%)\end{array}$ & & \\
\hline Private & 4 & 26.67 & 11 & 73.33 & 15 & 60.00 \\
\hline Public & 3 & 30.00 & 7 & 70.00 & 10 & 40.00 \\
\hline Total & 7 & 28.00 & 18 & 72.00 & 25 & 100.00 \\
\hline
\end{tabular}

\section{3: Water in Primary Schools in Obio-Akpor LGA}

\subsection{1: Source of water}

A study of the source of water in the primary schools visited showed that $1(4 \%)$ of the primary schools had piped water to the school premises, $22(88.00 \%)$ of the primary schools had borehole with electric pump and $2(8.00 \%)$ of the primary schools had no water supply, as shown in table 7.3 below;

Table 7.3: Water source in Primary Schools in Obio-Akpor LGA

\begin{tabular}{|l|c|c|}
\hline Water source & Absolute Frequency & Relative Frequency (\%) \\
\hline $\begin{array}{l}\text { Piped water to school } \\
\text { premises }\end{array}$ & 1 & 8.00 \\
\hline Bore hole with electric pump & 22 & 8.00 \\
\hline No water supply & 2 & 8.00 \\
\hline
\end{tabular}

\subsection{2: Functionality/Availability of Water in primary schools in Obio-Akpor LGA}

The study also revealed that; of the 23 primary schools that had a source of water, $18(78.26 \%)$ had constant water supply and 5 (21.74\%) occasionally had water supply, as shown in table 7.4 below; 
Assessment of the water facilities in primary schools in the Niger Delta. WASH education series 1.

Table 7.4: Water availability/functionality in Primary Schools

\begin{tabular}{|l|c|c|}
\hline $\begin{array}{l}\text { Water } \\
\text { functionality/Availability }\end{array}$ & Absolute Frequency & Relative Frequency (\%) \\
\hline Constant & 18 & 78.26 \\
\hline Occasional & 5 & 21.74 \\
\hline Total & 23 & 100.00 \\
\hline
\end{tabular}

\subsection{3: Distance from source of water to common point of use}

Also, of the 23 primary schools that had water supply, pupils in $20(86.96 \%)$ schools had to walk a distance of $<5$ minutes from the source to the common point of use, and pupils in $3(13.04 \%)$ schools had to walk $>5$ minutes, as shown in figure 7.1 below;

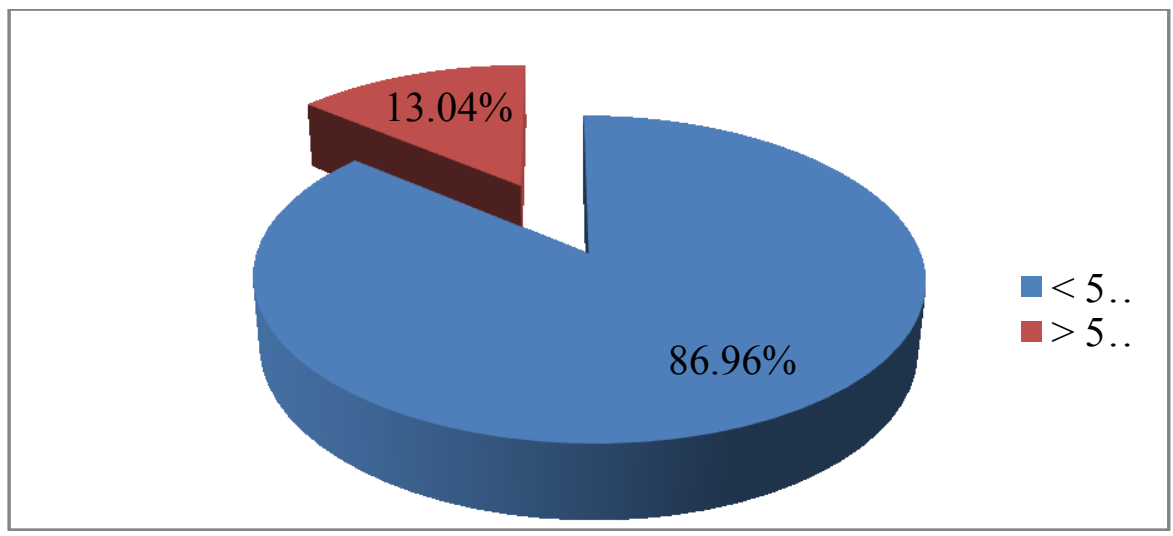

Figure 7.1: Distances from source of water to common point of use

\subsection{4: Provision for drinking water in Primary schools in Obio-Akpor LGA}

Furthermore, the study showed that; of the 25 primary schools, 5 (20\%) had provision for drinking water in the classrooms, $18(72 \%)$ of the primary schools had provision for drinking water in the school compound, and $2(8 \%)$ had no provision for drinking water, as shown in figure 7.2 below;

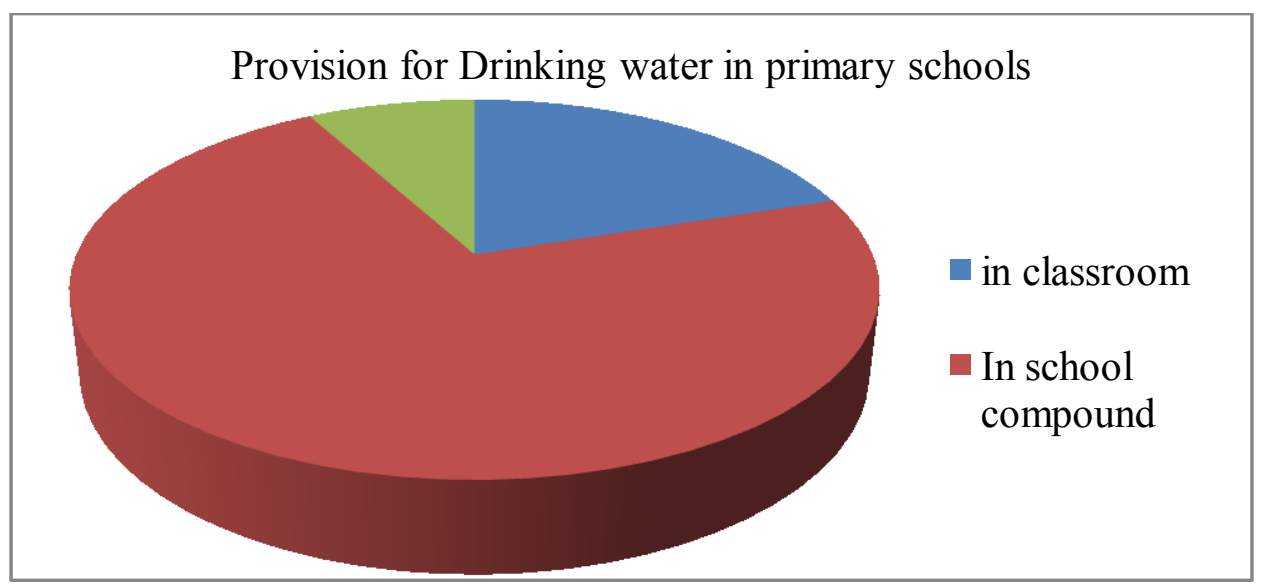

Figure 7.2: Provision for drinking water in Primary Schools in Obio-Akpor LGA

\section{Discussion}

Providing sufficient levels of water supply, sanitation and hygiene in schools is of immediate pertinence to the United Nations (UN) Millennium Development Goals of accomplishing universal basic education, promoting gender equality and diminishing child mortality. It is likewise steady of other goals, particularly those on significant diseases and child mortality. ${ }^{6,8}$ Hence, WASH mediations are apropos and differing, conceivably incorporating change in all angles; water access (e.g., water quality, water amount and separation to water), sanitation access (e.g., access to improved toilets, toilet support, and faecal slop 
administration), and hygiene polishes (e.g., hand washing before consuming and/or after poo, water treatment, cleanser use, wearing shoes and water stockpiling practices). ${ }^{9-18}$

For the purpose of this WASH study series, we will be discussing on assessment of water in terms of source, functionality/availability, distance and provision for drinking water in Primary schools in the Niger Delta.

In this study on the assessment of water sanitation and hygiene education (WASH), out of the 25 schools studied, 88\% (22) had borehole with electric pump (improved source) and 4\% (1) had piped water to the school premises as source of water supply. When compared to the study done in Imo State, in which rain water harvesting (unimproved source) was the main source of water supply, this was by far better. ${ }^{19}$ This may not be unconnected with the fact that Obio-Akpor Local Government Area is urban and commercially fast growing. However, 8\% (2) schools had no source of water supply, as they were occupying temporary locations owning to the on-going reconstruction of schools by the Rivers State Government.

Interestingly, $78 \%$ of schools studied had constant water supply. Also, of the 23 primary schools that had water supply, pupils in $20(86.96 \%)$ schools had to walk a distance of $<5$ minutes from the source to the common point of use, and pupils in $3(13.04 \%)$ schools had to walk $>5$ minutes which is in line with international standards as stated in section 3 of this document. ${ }^{6}$

This was better when compared with findings of a recent UNICEF commissioned study in Nigeria which reported that $64 \%$ of schools had no source of water. ${ }^{20}$

\section{Recommendations}

In order to improve the standard of Water Sanitation and Hygiene (WASH) in primary schools in ObioAkpor Local Government Area, we recommend the following;

- Public enlightenment and advocacy through mass media, workshops and seminars on the importance and need for proper funding of water sanitation and hygiene education in schools, and it's relevance in communicable disease prevention.

- Development of maintenance plan and proper supervision as well as constant supply of consumables such as soap and tissue paper in the recently constructed water, sanitation and hygiene facilities in the model primary schools in Obio-Akpor Local Government Area, already existing ones and private primary schools, through the establishment of a monitoring task force.

- The Primary Education Board should ensure strict compliance with admission proceedings such that the number of pupil admitted into both private and public primary schools do not exceed the capacity provided for by the existing water, sanitation and hygiene facilities in the respective schools.

\section{Conclusion}

The water facilities as observed from this study, met with internationally acceptable standards. However, development of maintenance plan and strict compliance with admission proceedings such that the number of pupil admitted into both private and public primary schools do not exceed the capacity provided for by the existing water facilities is inimical to communicable disease prevention.

\section{Acknowledgements}

To all the members, staff, teachers and pupils of the primary schools in Obio-akpor Local Government area of Rivers state. Accept our unreserved and unalloyed gratitude.

\section{References}

[1]. Goodman D L, Worden H V, Shordt K, Snell M. Water, Sanitation and Hygiene education for Schools. Oxford Roundtable. UK; Oxford University Press; 2005: 24.28

[2]. WHO. Cause specific mortality: regional estimates for 2008. Geneva, World Health Organization. 2011a, (http://www.who.int/healthinfo/global burden disease/estimates regional/en/index.html).

[3]. Liu et al. Global, regional and national causes of child mortality: an updated systematic analysis for 2010 with time trends since 2000. Lancet, 2012, 379: 2151-61.

[4]. WHO. Cholera, 2011. Weekly Epidermiological Report.

[5]. United Nations Children's Fund. Development of a Framework and an Action Plan for School Sanitation and Hygiene Education in Punjab. Innovative Consultant Limited. Dec 2007.

[6]. Adams J, Batrom J, Chartier Y, Sims J. Non serial Publication Series on Water, Sanitation and Hygiene Standards for Schools in low cost settings. Geneva; WHO; 2009: 2, 3, 18-23.

[7]. The Millennium Development Goals Report 2013 - UNDP. www.undp.org/content/undp/en/home/library.

[8]. Census Obio-Akpor, 2006.

[9]. Fewtrell L, Kaufmann RB, Kay D, Enanoria W, Haller L, et al. Water sanitation, and hygiene intervention to reduce diarrhoea in less developed countries: a systemic review and meta-analysis. Lancet Infect Dis 2005, 5: 42-52.

[10]. Clasen T, Roberts I, Rabie T, Schmidt W, Cairncross S. Intervention to improve water quality for preventing diarrhoea. Cochrane Database Syst Rev: 2006, CD004794.

[11]. Arnold B, Arana B, Mausezahl D, Hubbard A, Colford JM, Jr. Evaluation of pre-existing, 3-year household water treatment and handwashing intervention in rural Guatermala, Int J Epidemiol. 2009, 38:1651-1661. 
[12]. Caincross S, Hunt C, Boisson S, Bostoen K, Curtis V, et al. Water, Sanitation and hygiene for the prevention of diarrhoea. Int J Epidemiol 2010, 39 suppl 1: i193-i205.

[13]. Clasen TF, Bostoen K, Schmidt W-P, Boisson S, Fung ICH, et al. Interventions to improve disposal of human extreta for preventing diarrhoea. Cochrane Database Syst Rev: 2010, CD007180.

[14]. Graf J, Zebaze Togouet S, Kemka N, Niyitegeka D, Meierhofer R, et al. Health gains from solar water disinfection (SODIS): evaluation of a water quality intervention in Yaounde, Cameroon. J Water Health. 2010, 8: 779-796.

[15]. Hunter PR, Ramirez Toro GI, Minnigh HA. Impact on diarrhoeal illness of a community educational intervention to improve drinking water quality in rural communities in Puerto Rico. BMC Public Health. 2010, 10: 219.

[16]. Freeman MC, Clesen T. Assesing the impavt of a school-based safe water intervention on household adoption of point-of-use water treatment practices in southern India. Am J Trop Med Hyg. 2011, 84: 370-378.

[17]. Greene LE, Freeman MC, Akoko D, Saboori S, Moe C, et al. Impact of a school-based hygiene education promotion and sanitation intervention on pupil hand contamination in Western Kenya.: 2012, 87: 385-393.

[18]. Gruber JS, Reygadas F, Arnold BF, Ray I, Nelson K, et al. A stepped wedge, cluster-randomized trial of a household UVdisinfection and safe storage drinking water intervention in rural Baja California Sur, Mexico. Am J Trop Med Hyg. 2013, 89:238245 .

[19]. Asiabaka I P, Mbakwen J. Assessment of Facility Needs of Government Primary Schools in Imo State; Some neglected Areas. New York Science Journal 1(2); August 2008: 22 - 29.

[20]. United Nations Children's Fund. Water, Sanitation and Hygiene in Nigeria. Nigeria Country programme. Feb 2007. 